\title{
Effects of a waste water treatment plant on organic matter dyna- mics and ecosystem functioning in a Mediterranean stream
}

\author{
A. Ruggiero ${ }^{1 *}$, A.G. Solimini ${ }^{2}$, G. Carchini ${ }^{3}$ \\ ${ }^{1}$ Laboratoire d'Ecologie des Hydrosystèmes, UMR 5177, Université Paul Sabatier, 118 route de Narbonne, F-31062 Toulouse Cedex 9 , France. \\ 2 European Commission Joint Research Centre, Institute for Environment and Sustainability, Inland and Marine Waters Unit. Ispra, Italy. \\ ${ }^{3}$ Università di Roma Tor Vergata, Dipartimento di Biologia, Via della Ricerca Scientifica, 00133 Roma, Italy.
}

\begin{abstract}
We studied the effects of a waste water treatment plant on organic matter dynamics in Fosso Bagnatore, a Mediterranean stream near Rome (Italy). Concentrations of dissolved organic carbon and seston, along with the standing crops of coarse benthic organic matter and fine benthic organic matter, were monitored monthly during 2002 in two reaches situated upstream and downstream of a waste water treatment plant effluent. Additionally, we examined two stream functional characteristics: whole stream metabolism, which was measured from diel changes in oxygen concentrations, and nutrient removal, which was studied by experimental additions of $\mathrm{NH}_{4}-\mathrm{N}, \mathrm{NO}_{3}-\mathrm{N}$ and $\mathrm{PO}_{4}-\mathrm{P}$. The possible influence of WWTP organic matter alterations on ecosystem functioning was addressed by measuring epilithon characteristics (standing crop, C:N:P ratios and chlorophyll a content). The WWTP effluent caused an increase (several-fold) of DOC and seston concentrations, and FBOM standing crop, moreover it modified their temporal variation. Downstream of the wastewater treatment plant we detected an higher heterotrophic microbial biomass and a correspondent higher community respiration. The uptake of $\mathrm{NH}_{4}-\mathrm{N}, \mathrm{NO}_{3}-\mathrm{N}$ and $\mathrm{PO}_{4}-\mathrm{P}$ was highly variable probably as consequence of the high variability of the compartments involved (e.g. DOC, FBOM, community respiration). We showed that WWTP effluent altered the organic matter dynamics of this Mediterranean-type headwater stream and that these effects were reflected in its ecosystem functioning. Because of the linkage of headwaters to downstream ecosystems and due to their significant role in landscape and catchment processes, the alterations of organic matter dynamics that we detected at a local scale may have important consequences on a broader scale.
\end{abstract}

Keywords : DOC, seston, benthic organic matter, waste water treatment plant effluent, nutrient retention.

\section{Introduction}

River networks transport water and dissolved and particulate matter, including organic matter, from headwaters to downstream ecosystems. Thus they represent important dynamic components of landscapes, which are intimately influenced by the nature of their catchment (Tockner et al. 2003). Streams may constitute $85 \%$ of total channel length in the network of fluvial ecosystems (Peterson et al. 2001). Both dissolved and particulate forms of organic matter are considered to be fundamentally important for stream functioning.

\footnotetext{
* Corresponding author :

E-mails : antonio.ruggiero@cict.fr, antonio.ruggiero@uniroma2.it
}

Changes in the availability and quality of organic matter may affect stream metabolism, substrate stability, primary and secondary production, nutrient dynamics, and the abundance and composition of invertebrate stream communities (Benke et al. 1984, Jones 1997, Webster et al. 2000, Crenshaw et al. 2002, Fischer et al. 2002, Acuña et al. 2004, Artigas et al. 2004, Robinson \& Jolidon 2005). Humans may alter both temporal and spatial patterns of organic matter availability in streams. Timber harvest, wastewater disposal or removal of riparian vegetation are some examples of human activities resulting in changes of organic availability in streams (Golladay et al. 1989, Webster et al. 1990, Merseburger et al. 2005). Knowledge on the effects of human alterations on organic matter in streams, and its possible impacts on downstream reaches, is critical.

Article available at http://www.limnology-journal.org or http://dx.doi.org/10.1051/limn/2006014 
This is of particular interest in the Mediterranean area, which is a densely populated region experiencing scarcity of water supply and forest (Cobelas et al. 2005).

Streams have also been shown to play a key role in regulating the export of nutrients from catchments (D’Angelo \& Webster 1991, Elosegui et al. 1995, House \& Denison 1997, Johnson et al. 2000, Perakis \& Hedin 2002, Prior \& Johnes 2002). Nutrient removal is an important ecosystem service (sensu Costanza et al. 1997) ensured by streams, since it may influence the ecology of higher order streams and downstream habitats. The removal of nutrient from the stream water column can be parameterized in three ways (Stream Solute Workshop 1990): (i) the uptake rate U (mg m-2 min-1) is the mass flux of nutrient from the water column to the stream bottom; (ii) the uptake length $\mathrm{Sw}$ $(\mathrm{m})$ is the average distance a nutrient atom travels in the water column before it enters a streambed compartment; (iii) the uptake velocity Vf (mm min-1) is the theoretical velocity at which a nutrient atom moves from the water column to the stream substratum, as a result of a biological demand or a sorption process.

In this study, we report effects of a wastewater treatment plant (WWTP) on the spatial and temporal availability of organic matter in Fosso Bagnatore, a third order Mediterranean stream, and address the consequences of these effects on metabolism and nutrient removal efficiency in the stream. From January to December 2002, we conducted monthly samplings according to a fixed sampling protocol in order to estimate the concentrations of dissolved organic carbon (DOC) and particulate organic matter (seston) in the water column, and the standing crops of benthic organic matter (fine and coarse) in an experimental reach situated downstream of a municipal WWTP. The same protocol was performed in a control reach situated upstream of the WWTP. In these reaches we estimated uptake rates, uptake lengths and uptake velocities for $\mathrm{PO}_{4}-\mathrm{P}, \mathrm{NH}_{4}-\mathrm{N}$ and $\mathrm{NO}_{3}-\mathrm{N}$, too. The influence of organic matter alterations on the ecosystem metabolism and the nutrient stream removal efficiency was addressed by measuring epilithon characteristics: standing crop, $\mathrm{C}: \mathrm{N}: \mathrm{P}$ ratios and chlorophyll $a$ content.

\section{Study area}

Fosso Bagnatore $\left(12^{\circ} 02^{\prime} \mathrm{E}, 42^{\circ} 02^{\prime} \mathrm{N}\right)$ is a third order stream (10 km long and 2-4 m wide) located $50 \mathrm{~km}$ North-Est of Rome in Central Italy. Its headwaters are situated at $828 \mathrm{~m}$ a.s.l., while its confluence with the Aniene river is at $320 \mathrm{~m}$ a.s.l., which means an average slope of $72 \mathrm{~m} / \mathrm{km}$ and a mean annual discharge of
300-400 L s ${ }^{-1}$. The dominant substrates are rocks, cobbles and coarse gravel, with large pool areas behind dikes. Riparian vegetation is mainly constituted by $S a$ lix alba, Ulmus minor, Ranunculus spp, Urtica dioica, Arundo donax, Petasites hybridus and Sambucus nigra. The catchment $\left(19 \mathrm{~km}^{2}\right)$ is mainly constituted by limestone, dominant land uses are arable and grassland $(60 \%)$, forest and scrubland $(36 \%)$ and urban areas (4\%). The wastewater treatment plants (WWTP) of two villages (Riofreddo and Arsoli, 2318 inhabitants) represent the main nutrient point sources. Climate of the basin is of Mediterranean type, with rainfall mainly from September to December and annual precipitation ranging from 1000 to $1600 \mathrm{~mm} \mathrm{yr}^{-1}$.

\section{Material and methods}

\section{Organic matter}

From January to December 2002 we sampled monthly DOC, seston, BOM and epilithon in two reaches situated upstream and downstream of the WWTP of the Arsoli village (hereafter referred to as UP and DW respectively). In addition, we installed an automatic meter (Diver ${ }^{\circledR}$, Van Essen Instruments) in the downstream reach to monitor water level, water temperature and air temperature at 4-h intervals throughout the year.

Six water samples for determination of DOC and seston were collected in dark 500-ml polyethylene bottles, immediately stored in refrigerator boxes, and transported to the laboratory. On return to the laboratory, samples were filtered through pre-combusted glass microfiber filters (Whatman GF/F, 0.7 (m) and the filtered water was then stored until the analysis of DOC high-temperature catalytic oxidation (Shimadzu ${ }^{\circledR}$ TOC 5000 analyzer) (Wetzel \& Likens 1991). The samples from September to December are not available. The filters with retained material were dried $\left(60^{\circ} \mathrm{C}\right)$, weighed, combusted $\left(500^{\circ} \mathrm{C}\right)$ and reweighed to measure ash free dry mass (AFDM).

Six replicate samples of benthic organic matter (BOM) were collected with a Hess sampler $(20 \mathrm{~cm}$ diameter), washed in a mesh $(63 \mu \mathrm{m})$ and taken to the laboratory in plastic bags. Within 24 hours, samples were sorted under binocular microscope (10-50 x) and macroinvertebrates removed. The remaining material was poured through sieves to separate the coarse benthic organic matter $(\mathrm{CBOM}>1 \mathrm{~mm}$ diameter) from the fine benthic organic matter (FBOM in the size range of $>0.3 \mathrm{~mm}$ to $<1.0 \mathrm{~mm}$ ) and processed to determine the AFDM as for seston. 
Additionally, we collected six cobbles from each reach to measure the epilithon standing crop. On return to the laboratory the cobbles were stored in the refrigerator and processed within 24 hours: we scraped the cobbles surfaces, washed the material into a container, and then filtered two subsamples of this slurry through precombusted glass microfiber filters (Whatman $\mathrm{GF} / \mathrm{F}$, $0.7 \mu \mathrm{m})$. One subsample was processed to determine the Chlorophyll $a(\mathrm{Chl} a)$, after extraction in $90^{\circ}$ acetone overnight, by following the Lorenzen's method (Wetzel \& Likens 1991). The other subsample was processed to determine the AFDM as for seston. The area of each cobble was measured. Epilithon subsamples were collected over the whole study period to determine its $\mathrm{C}: \mathrm{N}, \mathrm{C}: \mathrm{P}$ and $\mathrm{N}: \mathrm{P}$ ratios. These subsamples were dried, weighted and ground, and analysed for $\mathrm{C}$ and $\mathrm{N}$ with CarloErba elemental analyser, while their P content was determined as TP after digestion with persulfate (Wetzel \& Likens 1991).

\section{Ecosystem metabolism}

Gross primary production (GPP), community respiration $(\mathrm{CR})$ and net ecosystem production (NEP) of the two experimental reaches were determined within a day of each addition experiment by the upstreamdownstream method (Marzolf et al. 1994). Dissolved oxygen concentration and water temperature $\left(\mathrm{WTW}^{\circledR}\right.$ $340 \mathrm{i})$ were measured at 15 -min intervals over a 24 -h period at the top end and at the bottom end of the experimental reach. The exchange of DO with the atmosphere was based on reaeration coefficients calculated by Owens et al. (1974), as reported in Hauer \& Lamberti (1996).

\section{Nutrient retention}

During 2002, we estimated stream nutrient removal efficiency in UP and DW on 6 and 7 dates, respectively. Nutrient removal efficiency was estimated using the slug addition technique (Gordon et al. 1994). A known volume of solution (e.g., nutrients + conservative tracer) was added all at once from a carboy in the midchannel at the top end of the reach. Once the solution was added, water samples were collected at regular intervals (about 1 every minute) at the bottom end of the reach with an increase in frequency (up to 1 every 5 seconds) during the solution's passage (which was detected by an increase of the stream background conductivity). The collection of samples stopped when conductivity values were at the same level as measured previous to the release. Concentration-time curve $\left(\mathrm{mg} \mathrm{L}^{-1}\right.$ $x$ s) of nutrient $\left(\mathrm{PO}_{4}-\mathrm{P}, \mathrm{NH}_{4}-\mathrm{N}\right.$ and $\left.\mathrm{NO}_{3}-\mathrm{N}\right)$ and conservative tracer (i.e. $\mathrm{Cl}^{-}$) were then used to calcula- te the mass ( $\mathrm{mg}$ ) of nutrient retained (see details of addition experiment, chemical analyses and calculation in Ruggiero et al. 2006). We calculated the nutrient uptake rate ( $\left.\mathrm{U}, \mathrm{mg} \mathrm{m}^{-2} \mathrm{~min}^{-1}\right)$ by dividing the mass of nutrient removed from the water column during the addition experiment by the stream bottom area $\mathrm{A}\left(\mathrm{m}^{2}\right)$ of the reach and by the time $\mathrm{T}(\mathrm{min})$ of the duration of the addition. The nutrient uptake length $(\mathrm{Sw}, \mathrm{m})$ was then estimated from:

$$
\mathrm{Sw}=\left([\mathrm{Nut}]_{\mathrm{b}} * \mathrm{Q}\right) /(\mathrm{U} * \mathrm{w})
$$

Where $[\mathrm{Nut}]_{\mathrm{b}}$ is the nutrient background concentration $\left(\mathrm{mg} \mathrm{L}^{-1}\right), \mathrm{Q}$ is the discharge $\left(\mathrm{m}^{3} \mathrm{~s}^{-1}\right), \mathrm{U}$ is the nutrient uptake rate $\left(\mathrm{mg} \mathrm{m}^{-2} \mathrm{~s}^{-1}\right)$ and $\mathrm{w}(\mathrm{m})$ is the average stream width of the reach. The nutrient uptake velocity $\left(\mathrm{V}_{\mathrm{f}}, \mathrm{mm} \mathrm{s}^{-1}\right)$ was estimated from:

$\mathrm{V}_{\mathrm{f}}=\mathrm{U} /[\mathrm{Nut}]_{\mathrm{b}}$

Where $\mathrm{U}$ is the nutrient uptake rate $\left(\mathrm{mg} \mathrm{m}^{-2} \mathrm{~s}^{-1}\right)$, $[\mathrm{Nut}]_{\mathrm{b}}$ is the nutrient background concentration $\left(\mathrm{mg} \mathrm{L}^{-1}\right)$.

\section{Statistical analysis}

Differences in DOC, seston, CBOM, FBOM, epilithon and in Chla of the epilithon algal component between UP and DW were tested with Paired samples ttest. Differences in epilithon molar C:N and N:P ratios, $[\mathrm{Nut}]_{\mathrm{b}}, \mathrm{U}, \mathrm{S}_{\mathrm{w}}, \mathrm{V}_{\mathrm{f}}, \mathrm{GPP}, \mathrm{CR}$ and NEP between UP and DW were tested with analysis of variance (ANOVA) test. All data are presented as the mean \pm SE.

\section{Results}

\section{Climate setting}

The annual precipitation of 2002 reached $1022 \mathrm{~mm}$ in the area of Fosso Bagnatore, with almost the $50 \%$ of the total rainfall occurring between August and November (Fig.1). Stream discharge ranged from $2.6 \mathrm{~L} \mathrm{~s}^{-1}$ to $26.7 \mathrm{~L} \mathrm{~s}^{-1}$ at the monitoring site, and averaged $9.9 \pm$ $0.31 \mathrm{~L} \mathrm{~s}^{-1}$ (Fig.1); water and air temperature ranged from $1.6^{\circ} \mathrm{C}$ to $22.8^{\circ} \mathrm{C}$ and from $-0.2^{\circ} \mathrm{C}$ to $25.6^{\circ} \mathrm{C}$ respectively, averaging $13.0 \pm 0.3^{\circ} \mathrm{C}$ and $13.6 \pm 0.3^{\circ} \mathrm{C}$ respectively, and peaking in July-August (Fig. 1).

\section{Organic matter}

DOC concentration ranged from $1.7 \pm 0.1$ (UP, June) to 50.9 (DW, August) mg L-1 (Fig. 2a). The annual mean was significantly higher in DW with $16.8 \pm 5.8$ $\mathrm{mg} \mathrm{L}^{-1}$ than in UP with $2.8 \pm 0.6 \mathrm{mg} \mathrm{L}^{-1}$ (Paired Samples t-test, $\mathrm{t}=2.674, \mathrm{p}<0.05)$. Seston concentration ranged from 2.2 (UP, October) to $83.6 \pm 15.95$ 


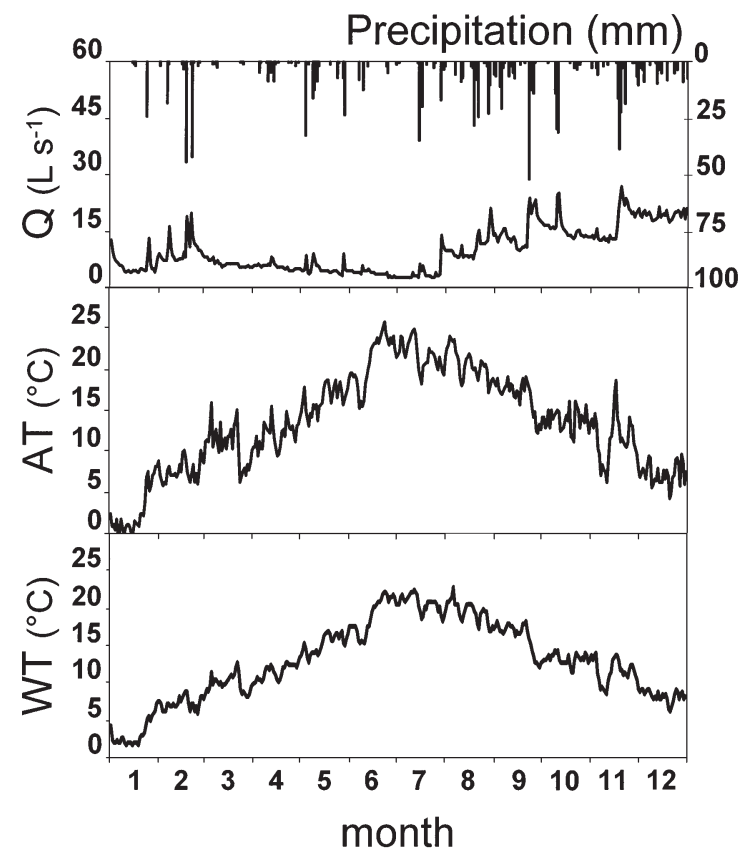

Fig. 1. Mean daily discharge (Q), precipitation, air temperature (AT) and water temperature (WT) record in Fosso Bagnatore over the year 2002.

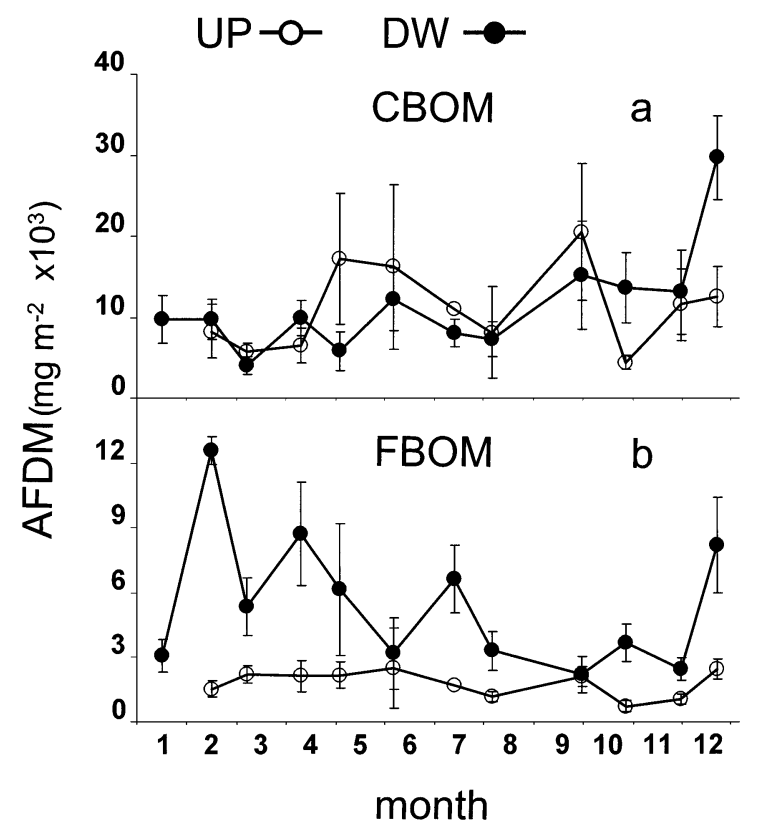

Fig. 3. Temporal patterns of coarse benthic organic matter (a) and fine benthic organic matter (b) (mean \pm SE) from January to December 2002 .

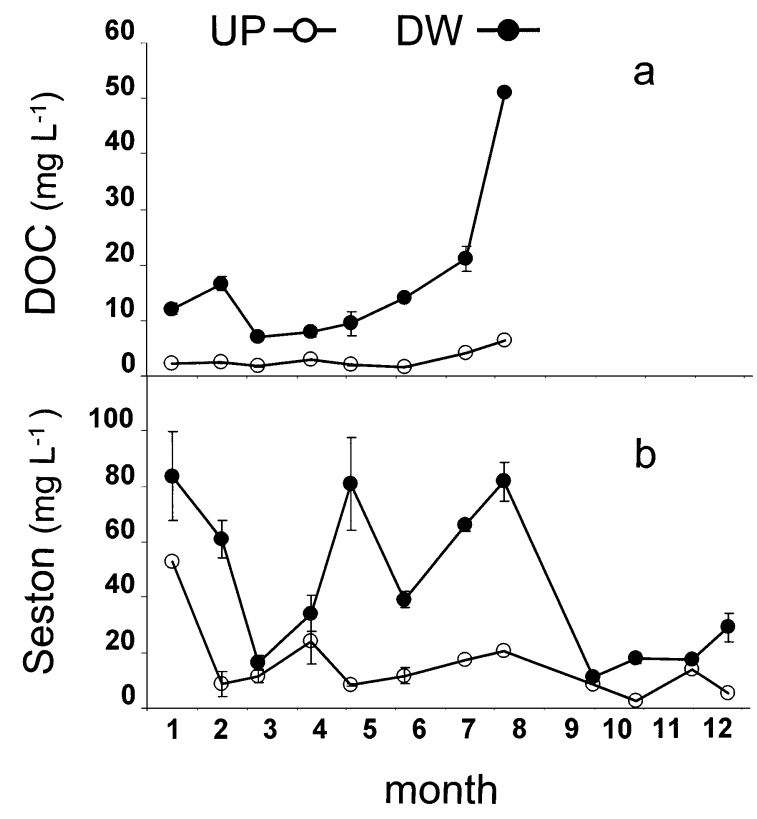

Fig. 2. Temporal patterns of dissolved organic carbon (a) and seston (b) (mean \pm SE) from January to December 2002.

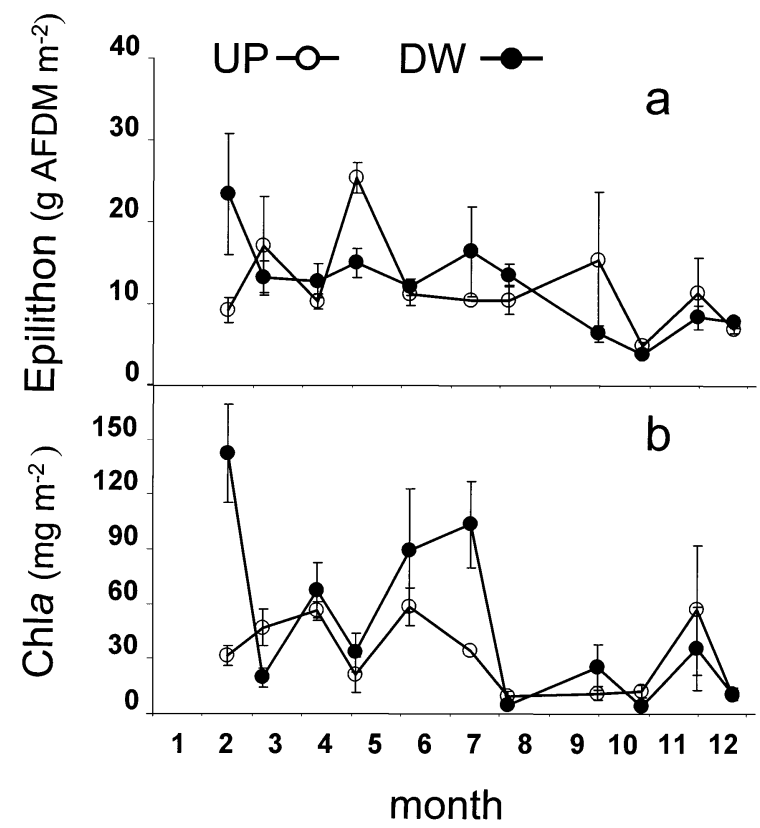

Fig. 4. Temporal patterns of epilithon (a) and chlorophyll $a$ of the algal component within the epilithon (b) (mean \pm SE) from January to December 2002 . 
(DW, January) mg L-1(Figure 2b) and was significantly higher in DW with $46.0 \pm 8.9 \mathrm{mg} \mathrm{L}^{-1}$ than in UP with $15.7 \pm 4.6 \mathrm{mg} \mathrm{L}^{-1}$ (Paired Samples t-test, $\mathrm{t}=3.959$, $\mathrm{p}<0.005)$. The standing crop of CBOM ranged from $4084 \pm 1064$ (DW, March) to $29708 \pm 5181$ (DW, December) mg AFDM m ${ }^{-2}$ (Figure $3 \mathrm{a}$ ), and values were not significantly different between sites (Paired Samples t-test, $\mathrm{t}=0.384, \mathrm{p}=0.710$ ). The standing crop of FBOM ranged from $720 \pm 283$ (UP, October) to $12560 \pm 655$ (DW, February) $\mathrm{mg}^{\text {AFDM m}}{ }^{-2}$ (Figure $3 \mathrm{~b})$ and was significantly higher in DW with $5575 \pm$ $1062 \mathrm{mg} \mathrm{AFDM} \mathrm{m}^{-2}$ than in UP with $1800 \pm 199 \mathrm{mg}$ AFDM m-2 (Paired Samples $\mathrm{t}$ Test, $\mathrm{t}=3.636, \mathrm{P}<$ $0.01)$. The standing crop of epilithon ranged from 3.9 \pm 0.2 (DW, October) to $25.3 \pm 1.9$ (UP, May) g AFDM $\mathrm{m}^{-2}$ (Figure 4a) and differences were not significant between reaches (Paired Samples t-test, $\mathrm{t}=-0.247, \mathrm{p}=$ 0.810). On average the epilithon molar $\mathrm{C}: \mathrm{N}$ ratio was significantly higher at UP $(21.6 \pm 1.2)$ than at DW $(15.9 \pm 1.9)$ (ANOVA, $\mathrm{p}<0.05)$. On the other hand, $\mathrm{C}: \mathrm{P}$ ratios were similar in UP and in DW $(164 \pm 44$ and $134 \pm 16$ respectively) and $\mathrm{N}: \mathrm{P}(7.69 \pm 2.16$ and $8.42 \pm$ 0.29 respectively) ratios (ANOVA, n.s.). Chla ranged from $4.33 \pm 1.46 \mathrm{mg} \mathrm{m}^{-2}$ (DW) to $142.19 \pm 26.79 \mathrm{mg}$ $\mathrm{m}^{-2}$ (DW) $\mathrm{mg} \mathrm{m}^{-2}$ (Figure 4b) and differences between sites were not significant (Paired Samples t-test, $\mathrm{t}=$ $0.966, \mathrm{p}=0.359)$.

\section{Nutrient retention}

Nutrient uptake lengths ranged from $360 \mathrm{~m}\left(\mathrm{NH}_{4}-\mathrm{N}\right.$, UP reach, June) to $20579 \mathrm{~m}$ ( $\mathrm{PO}_{4}$-P, UP reach, March) (Table 1). They were quite variable, as their coefficients of variation ranged from $48 \%\left(\mathrm{NH}_{4}-\mathrm{N}, \mathrm{DW}\right)$ to $136 \%\left(\mathrm{NO}_{3}-\mathrm{N}, \mathrm{UP}\right)$. On average the ammonium uptake length was estimated in the order of one kilometer in UP and in the order of two kilometers in DW but this difference was not statistically significant (ANOVA n.s.). The $\mathrm{NO}_{3}-\mathrm{N}$ and $\mathrm{PO}_{4}-\mathrm{P}$ uptake lengths were in the order of kilometers in either UP and DW and quite similar (ANOVA n.s.). $\mathrm{NH}_{4}-\mathrm{N}$ was removed more efficiently from the water column than $\mathrm{NO}_{3}-\mathrm{N}$ and $\mathrm{PO}_{4}-\mathrm{P}$ in either UP and DW: the average ratio of $\mathrm{S}_{\mathrm{w}(\mathrm{NH} 4-\mathrm{N})}$ to $\mathrm{S}_{\mathrm{w}(\mathrm{NO} 3-\mathrm{N})}$ and to $\mathrm{S}_{\mathrm{w}(\mathrm{PO} 4-\mathrm{P})}$ was of 0.76 and of 0.19 respectively in UP, and of 0.82 and 0.86 respectively in DW. Stream efficiency in removing $\mathrm{NO}_{3}-\mathrm{N}$ and $\mathrm{PO}_{4}-\mathrm{P}$ from the water column was similar in either UP and DW with the ratio of $\mathrm{S}_{\mathrm{w}(\mathrm{NO} 3-\mathrm{N})}$ to $\mathrm{S}_{\mathrm{W}(\mathrm{PO} 4-\mathrm{P})}$ ranging from 0.04 (UP $14 \mathrm{March}$ ) to 7.38 (DW 04 June).

Uptake rates ranged from $0.001\left(\mathrm{NH}_{4}-\mathrm{N}, \mathrm{UP}, \mathrm{June}\right)$ to $2.117\left(\mathrm{NH}_{4}-\mathrm{N}, \mathrm{DW}, 29\right.$ April $) \mathrm{mg} \mathrm{m}^{-2} \mathrm{~min}^{-1}$ (Table 1). They varied considerably with their coefficients of variation ranging from $47 \%\left(\mathrm{NH}_{4}-\mathrm{N}, \mathrm{DW}\right)$ to $145 \%\left(\mathrm{NO}_{3}-\mathrm{N}, \mathrm{UP}\right)$. On average, the $\mathrm{NH}_{4}-\mathrm{N}$ uptake rate was higher in DW than in UP (ANOVA, p

Table 1. Uptake length $\left(\mathrm{S}_{\mathrm{W}}\right)$, uptake rate $(\mathrm{U})$ and uptake velocity $\left(\mathrm{V}_{\mathrm{f}}\right)$ estimates for $\mathrm{NH}_{4^{-}}$ $\mathrm{N}, \mathrm{NO}_{3}-\mathrm{N}$ and $\mathrm{PO}_{4}-\mathrm{P}$ in the experimental reaches for each addition experiment date. n.a. $=$ not available.

\begin{tabular}{|c|c|c|c|c|c|c|c|c|c|}
\hline \multirow[b]{2}{*}{ Date } & \multirow{2}{*}{\multicolumn{2}{|c|}{$\begin{array}{l}\mathrm{S}_{\mathrm{w}}(\mathrm{m}) \\
\mathrm{NO}_{3}-\mathrm{N}\end{array}$}} & \multirow[b]{2}{*}{$\mathrm{PO}_{4}-\mathrm{P}$} & \multicolumn{3}{|c|}{$\mathrm{U}\left(\mathrm{mg} \mathrm{m}^{-2} \min ^{-1}\right)$} & \multicolumn{3}{|c|}{$V_{f}\left(m m \min ^{-1}\right)$} \\
\hline & & & & $\mathrm{NH}_{4}-\mathrm{N}$ & $\mathrm{NO}_{3}-\mathrm{N}$ & $\mathrm{PO}_{4}-\mathrm{P}$ & $\mathrm{NH}_{4}-\mathrm{N}$ & $\mathrm{NO}_{3}-\mathrm{N}$ & $\mathrm{PO}_{4}-\mathrm{P}$ \\
\hline & \multicolumn{9}{|c|}{ UP REACH } \\
\hline 14 Feb 02 & n.a. & n.a. & 2334 & n.a. & n.a. & 0.062 & n.a. & n.a. & 0.160 \\
\hline 14 Mar 02 & 1878 & 714 & 20579 & 0.008 & 1.766 & 0.005 & 0.216 & 0.567 & 0.020 \\
\hline 05 Apr 02 & 698 & 18383 & 3892 & 0.010 & 0.045 & 0.013 & 0.364 & 0.014 & 0.065 \\
\hline 30 Apr 02 & 679 & 2957 & 4143 & 0.008 & 0.240 & 0.011 & 0.182 & 0.042 & 0.030 \\
\hline 05 Jun 02 & 360 & 2295 & 1124 & 0.001 & 0.177 & 0.044 & 0.073 & 0.011 & 0.023 \\
\hline \multirow[t]{2}{*}{$\begin{array}{r}\text { Mean } \\
(\mathrm{SE})\end{array}$} & $\begin{array}{c}904 \\
(334)\end{array}$ & $\begin{array}{c}6087 \\
(4126)\end{array}$ & $\begin{array}{c}6414 \\
(3583)\end{array}$ & $\begin{array}{c}0.007 \\
(0.002)\end{array}$ & $\begin{array}{c}0.557 \\
(0.405)\end{array}$ & $\begin{array}{c}0.027 \\
(0.011)\end{array}$ & $\begin{array}{c}0.209 \\
(0.060)\end{array}$ & $\begin{array}{c}0.159 \\
(0.136)\end{array}$ & $\begin{array}{c}0.060 \\
(0.026)\end{array}$ \\
\hline & \multicolumn{9}{|c|}{ DW REACH } \\
\hline 14 Feb 02 & 2770 & n.a. & 7747 & 1.959 & n.a. & 0.033 & 0.129 & n.a. & 0.046 \\
\hline 13 Mar 02 & 2329 & 3803 & 6762 & 1.425 & 0.997 & 0.009 & 0.199 & 0.122 & 0.068 \\
\hline 04 Apr 02 & 3542 & 2003 & 1552 & 0.397 & 0.914 & 0.052 & 0.117 & 0.208 & 0.221 \\
\hline 29 Apr 02 & 1136 & n.a. & 1242 & 2.117 & n.a. & 0.091 & 0.248 & n.a. & 0.227 \\
\hline 04 Jun 02 & 1417 & 15356 & 2080 & 1.011 & 0.111 & 0.076 & 0.081 & 0.008 & 0.056 \\
\hline $01 \mathrm{Jul} 02$ & 1174 & n.a. & 1166 & 1.162 & n.a. & 0.278 & 0.177 & n.a. & 0.178 \\
\hline $\begin{array}{r}\text { Mean } \\
(\mathrm{SE})\end{array}$ & $\begin{array}{l}2061 \\
(401)\end{array}$ & $\begin{array}{c}7054 \\
(4183)\end{array}$ & $\begin{array}{c}3480 \\
(1209)\end{array}$ & $\begin{array}{c}1.345 \\
(0.260)\end{array}$ & $\begin{array}{c}0.674 \\
(0.283)\end{array}$ & $\begin{array}{c}0.090 \\
(0.040)\end{array}$ & $\begin{array}{c}0.159 \\
(0.025)\end{array}$ & $\begin{array}{c}0.113 \\
(0.100)\end{array}$ & $\begin{array}{c}0.133 \\
(0.035)\end{array}$ \\
\hline
\end{tabular}


$<0.005$ ) reaching the values of 1.345 and $0.007 \mathrm{mg} \mathrm{m}^{-}$ ${ }^{2} \mathrm{~min}^{-1}$ in the two reaches, respectively. The uptake rate value estimated in $\mathrm{DW}$ for $\mathrm{PO}_{4}-\mathrm{P}$ was twice the value estimated in UP, but this difference was not statistically significant (ANOVA n.s.). The $\mathrm{NO}_{3}-\mathrm{N}$ uptake rates were similar in UP and DW. Most of the nitrogen uptake was met mainly by $\mathrm{NO}_{3}-\mathrm{N}$ in UP (ratio of $\mathrm{U}_{\mathrm{NH} 4-\mathrm{N}}$ to $\mathrm{U}_{\mathrm{NO} 3-\mathrm{N}}<1$ ), while it was met mainly by $\mathrm{NH}_{4}-\mathrm{N}$ in DW (ratio of $\mathrm{U}_{\mathrm{NH} 4-\mathrm{N}}$ to $\mathrm{U}_{\mathrm{NO}-\mathrm{N}}>1$ ). Total nitrogen uptake exceeded $\mathrm{PO}_{4}-\mathrm{P}$ uptake in either UP and DW with an average ratio of $\mathrm{U}_{(\mathrm{NO} 3-\mathrm{N}+\mathrm{NH} 4-\mathrm{N})}$ to $\mathrm{U}_{\mathrm{PO} 4-\mathrm{P}}$ of 102 and of 68 respectively. Phosphorus uptake exceeded ammonium uptake in UP where we calculated an average ratio of $\mathrm{U}_{\mathrm{NH} 4-\mathrm{N}}$ to $\mathrm{U}_{\mathrm{PO} 4-\mathrm{P}}$ of 0.79 , the contrary was detected in DW where the average value of $\mathrm{U}_{\mathrm{NH} 4-\mathrm{N}}$ to $\mathrm{U}_{\mathrm{PO} 4-\mathrm{P}}$ was of 45.86 .

Uptake velocities ranged from $0.008\left(\mathrm{NO}_{3}-\mathrm{N}, \mathrm{DW}\right.$, June) to $0.364\left(\mathrm{NH}_{4}-\mathrm{N}\right.$, UP, 05 April $) \mathrm{mm} \mathrm{min}^{-1}$ (Table 1). They varied considerably as their coefficients of variation ranged from $38 \%\left(\mathrm{NH}_{4}-\mathrm{N}, \mathrm{DW}\right)$ to $172 \%\left(\mathrm{NO}_{3}-\mathrm{N}, \mathrm{UP}\right)$. On average, the $\mathrm{V}_{\mathrm{f}}$ values estimated for $\mathrm{NH}_{4}-\mathrm{N}, \mathrm{NO}_{3}-\mathrm{N}$ and $\mathrm{PO}_{4}-\mathrm{P}$ were not significantly different between the two reaches (ANOVA, n.s.).

The background concentration of $\mathrm{NH}_{4}-\mathrm{N}$ was 100 times higher downstream of the WWTP (ANOVA, p < 0.001) (Table 2). On average, $\mathrm{PO}_{4}-\mathrm{P}$ and $\mathrm{NO}_{3}-\mathrm{N}$ background concentrations resulted 2 times higher in DW than in UP but these differences were marginally significant (ANOVA, $\mathrm{p}<0.1$ ).

\section{Ecosystem metabolism}

GPP was generally low in UP and quite null in DW (Table 2). CR values ranged from 2.1 (UP, 30 April) to 46.2 (DW, 29 April) $\mathrm{g} \mathrm{O}_{2} \mathrm{~m}^{-2} \mathrm{~d}^{-1}$. On average, it was higher in DW than in UP (ANOVA, $\mathrm{p}<0.05)$ reaching the value of $29.3( \pm 6.1)$ and $5.4( \pm 1.3) \mathrm{gO}_{2} \mathrm{~m}^{-2} \mathrm{~d}^{-1}$ in the two reaches respectively. NEP values ranged from 46.2 (DW, 29 April) to -1.4 (UP, 30 April) $\mathrm{g} \mathrm{O}_{2} \mathrm{~m}^{-2} \mathrm{~d}^{-1}$. On average, it was higher in UP than in DW (ANOVA, $\mathrm{p}<0.05)$ reaching the value of $-4.1( \pm 2.4)$ and $-29.0( \pm$ 15.1) $\mathrm{gO}_{2} \mathrm{~m}^{-2} \mathrm{~d}^{-1}$ in the two reaches respectively.

\section{Discussion}

\section{Climate setting}

The climatic and geomorphic setting strongly influences the structural and functional features of rivers and streams. The annual discharge of Fosso Bagnatore showed a quite evident seasonal variability which followed the rainfall pattern as expected for Mediterra-
Table 2. Background concentrations of $\mathrm{NH}_{4}-\mathrm{N}, \mathrm{NO}_{3}-\mathrm{N}$ and $\mathrm{PO}_{4}-\mathrm{P}$ and ecosystem metabolism in the experimental reaches for each addition experiment date. $\mathrm{GPP}=$ gross primary production; $\mathrm{CR}=$ community respiration; $\mathrm{NEP}=$ net ecosystem production. n.a. $=$ not available.

\begin{tabular}{|c|c|c|c|c|c|c|}
\hline \multirow[b]{2}{*}{ Date } & \multicolumn{3}{|c|}{$\begin{array}{l}\text { Background concentration } \\
\qquad\left(\mathrm{mg} \mathrm{L}^{-1}\right)\end{array}$} & \multicolumn{3}{|c|}{ 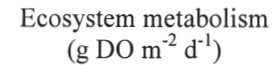 } \\
\hline & $\mathrm{NH}_{4}-\mathrm{N}$ & $\mathrm{NO}_{3}-\mathrm{N}$ & $\mathrm{PO}_{4}-\mathrm{P}$ & GPP & CR & NEP \\
\hline & \multicolumn{6}{|c|}{ UP REACH } \\
\hline 14 Feb 02 & 0.256 & 4.22 & 0.532 & 1.0 & 7.9 & -6.9 \\
\hline 14 Mar 02 & 0.037 & 3.29 & 0.251 & n.a. & n.a. & n.a. \\
\hline 05 Apr 02 & 0.039 & 4.64 & 0.294 & 1.9 & 7.1 & -5.2 \\
\hline 30 Apr 02 & 0.043 & 5.43 & 0.347 & 0.7 & 2.1 & -1.4 \\
\hline 05 Jun 02 & 0.005 & 3.53 & 0.427 & 1.4 & 4.5 & -3.1 \\
\hline \multirow[t]{2}{*}{$\begin{array}{r}\text { Mean } \\
(\mathrm{SE})\end{array}$} & $\begin{array}{c}0.076 \\
(0.046)\end{array}$ & $\begin{array}{c}4.22 \\
(0.39)\end{array}$ & $\begin{array}{c}0.37 \\
(0.05)\end{array}$ & $\begin{array}{c}1.3 \\
(0.27)\end{array}$ & $\begin{array}{c}5.4 \\
(1.3)\end{array}$ & $\begin{array}{l}-4.1 \\
(1.2)\end{array}$ \\
\hline & \multicolumn{6}{|c|}{ DW REACH } \\
\hline 14 Feb 02 & 17.63 & 0.11 & 0.831 & $<0.1$ & 10.1 & -10.1 \\
\hline 13 Mar 02 & 7.78 & 8.88 & 0.135 & 1.8 & 25.0 & -23.2 \\
\hline 04 Apr 02 & 6.91 & 8.99 & 0.485 & $<0.1$ & 19.6 & -19.6 \\
\hline $29 \mathrm{Apr} 02$ & 13.21 & 9.15 & 0.621 & $<0.1$ & 46.2 & -46.2 \\
\hline 04 Jun 02 & 14.39 & 17.11 & 1.589 & $<0.1$ & 26.9 & -26.9 \\
\hline $01 \mathrm{Jul} 02$ & 5.84 & 14.81 & 1.389 & $<0.1$ & 47.8 & -47.8 \\
\hline $\begin{array}{r}\text { Mean } \\
(\mathrm{SE})\end{array}$ & $\begin{array}{l}10.96 \\
(1.95)\end{array}$ & $\begin{array}{c}9.84 \\
(2.41)\end{array}$ & $\begin{array}{c}0.84 \\
(0.23)\end{array}$ & $\begin{array}{c}0.3 \\
(0.3)\end{array}$ & $\begin{array}{l}29.3 \\
(6.1)\end{array}$ & $\begin{array}{l}-29.0 \\
(6.1)\end{array}$ \\
\hline
\end{tabular}

nean-type streams (Resh et al. 1990, Cobelas et al. 2005). Even if seasonality seems rather weak and floods small, when compared to data published for other Mediterranean streams (Ahearn et al. 2004, Acuña et al. 2005), the hydrograph of Fosso Bagnatore with its marked peaks is characteristic for stream systems with small catchments (Gordon et al. 1994). High discharge occurred mainly in late autumn/winter and coincided with low temperatures and rainfall events. Local geomorphology probably played a major role in the hydro-dynamics of the stream, as the dominant karst geology of Fosso Bagnatore may cause loss of stream water from the surface channel to the karst aquifer.

\section{DOC and seston}

The DOC concentration in UP, our control reach, was within the range found for other headwater Mediterranean streams (Vidal-Abarca et al. 2001, Meixner \& Fenn 2004, Butturini et al. 2006). In the same reach, seston concentration ranged within the values reported for a number of intensively studied streams (Golladay 
1997), with the exception of the first sampling day when its concentration was particularly high. In Mediterranean-type streams, the variability of DOC and seston concentrations can be explained by the number and intensity of flood events. These may mobilize the organic matter, stored in soil and ground water during base flow and/or dry periods (Butturini \& Sabater 2000, Ahearn et al. 2004, Belnap et al. 2005). Also for this reason, organic matter forms such as DOC may be only weakly related to the seasonality of variables such as discharge (Bernal et al. 2005). Accordingly, as we collected our data on a monthly basis without considering the flood events, we did not detect any clear temporal pattern for DOC and seston concentrations in UP.

The WWTP effluent caused a several-fold increase in the DOC concentration in the DW reach, with the highest values during the summer. Seston concentration also increased ( $\mathrm{ca}$ 4-fold) downstream of the $\mathrm{Ar}$ soli WWTP, this being particularly evident during the summer period. Due to the tourism in this area an increment of inhabitants of Arsoli village occurs at this time. This fact may in part explain the increase of DOC and seston concentrations detected in DW. This possibility is confirmed by an increase of DOC and seston concentrations observed in the WWTP effluent during the same period (unpublished data). A second possible explanation, which is likely to be complementary to the previous one, is that a smaller dilution of the WWTP effluent probably occurs during the summer. This fact is a consequence of the lower discharge occurring in this season, and has been reported for other similar situations (Martì et al. 2004).

\section{CBOM and FBOM}

In streams, the standing crop of benthic organic matter is a close function of the input from the surrounding areas, and of the retention capacity of the stream (Karlsson et al. 2005, Lepori et al. 2005, Golladay et al. 1989). In Mediterranean-type streams, the input of organic matter peaks in autumn with litter fall, but it may continue throughout the year due to lateral input of wood and leaf debris (Sabater et al. 2001, Bañuelos et al. 2004). Yet it may be complicated to identify a clear seasonal pattern of the benthic organic matter standing crop in these streams due to the high inter-annual variability of their hydrological regime (Gasith \& Resh 1999). On the one hand, WWTP effluent did not affect the standing crop of CBOM, as the two reaches showed similar values and a similar temporal pattern. The temporal variation indicates that, between April and June, the accumulated CBOM showed values si- milar to those recorded in autumn. This is not surprising if we consider that during this period of low flow the retention capacity of streams can be enhanced (Acuña et al. 2004, Speaker et al. 1984). On the other hand, our data show that the WWTP effluent caused an increase in FBOM standing crop which was 3-fold higher in DW than in UP. Even if the temporal pattern of FBOM standing crop was quite similar in the two reaches, with a decreasing trend from winter to autumn and an increase in December, its coefficient of variation was $58 \%$ in DW and $35 \%$ in UP. This result indicates a higher temporal variation of FBOM standing crop downstream of the WWTP. Due to the fact that WWTPs emit particulate organic matter (Rauter et al. 2005, Ulseth \& Hershey 2005) an increase of FBOM standing crop was expected in DW (but see Ortiz et al. 2005). The seston concentration reported above for DW, and some very high seston concentrations (e.g. daily mean calculated on 9 observations $=428 \mathrm{mg} \mathrm{L}^{-1}$ ) that we have detected directly in the WWTP effluent (unpublished data), support the idea that a huge amount of fine particular organic matter was released from the WWTP into the stream throughout the year. According to the values of FPOM transport distances reported for other streams (Paul \& Hall 2002, Rauter et al. 2005) we can assume that a significant part of the seston released by the WWTP deposited and accumulated as FBOM in DW, which extended within the first $150 \mathrm{~m}$ below the WWTP. In fact, the huge FBOM standing stock in DW may also explain the higher temporal variation detected in this reach. Assuming a similar efficiency in retaining FBOM between UP and DW, the removal of stored organic matter which usually occurs at higher discharges (Brookshire \& Dwire 2003, Acuña et al. 2004) had more drastic effects in DW than in UP, this being probably more evident during floods events.

\section{Epilithon}

DOC, seston and FBOM represent sources of organic matter for heterotrophic microbes. We thus expected an increase in the epilithon standing crop below the WWTP effluent. In fact, we did not observe any significant difference between the two reaches for this biological variable. However, we did find a significant difference in the $\mathrm{C}: \mathrm{N}$ ratio of epilithon between the two reaches, which was higher in UP than in DW. On the one hand, the low $\mathrm{C}: \mathrm{N}$ ratio in $\mathrm{DW}$ may be a direct consequence of the presence of organic particles washed out from the WWTP (Rauter et al. 2005). Indeed, the suspended particulate matter just downstream of a WWTP can become very rich in N (Ulseth \& Hershey 2005) and low $\mathrm{C}: \mathrm{N}$ ratios indicate an anthropogenic 
origin of the fine particulate matter downstream of urban areas (Krusche et al. 2002, Marshal 2004). On the other hand, if we assume that the bulk of nitrogen in the epilithon is mainly represented by living organic matter (Dodds et al. 2000) we may conclude that despite no difference in the standing crop, the DW epilithon had a higher percentage of living organic matter. In practice, these two possible explanations are likely to be complementary rather than strict alternatives. However, we think the latter would be dominant, as we observed large filamentous bulking of Sphaerotilus sp. in DW during each visit. Moreover, since the Chla of the epilithon algal component does not change, we suggest that this increment of living organic matter was mainly due to heterotrophic organisms. This fact would be a direct consequence of WWTP effluent since DOC, seston and FBOM represent easily degradable organic matter which have been shown to favour the presence of high heterotrophic microbial biomass (Munn \& Mayer 1990, Mulholland et al. 2001).

\section{Ecosystem metabolism}

Taken together, the above facts suggest a possible higher heterotrophic microbial activity in DW than in UP. Our data on metabolism indicate both reaches were mainly heterotrophic $(\mathrm{NEP}<0)$ as expected for headwaters stream in forested catchments (Vannote et al. 1980). In comparison with other streams, GPP in UP was low (Acuña et al. 2004 and references therein, Gücker \& Pusch 2006) with the highest value occurring in spring. In DW, we recorded the maximum value of GPP in the same season, but it remained in practice null on all other dates. Accordingly, the community respiration dominated the ecosystem metabolism of the two reaches. Particularly in DW, the values of community respiration were extremely high. Considering the low values of GPP in UP and its almost null values in DW, we may consider the NEP as an indirect measure of the heterotrophic microbial activity. Therefore, we may conclude that downstream of the WWTP effluent, the heterotrophic microbial activity was 7-fold higher than in the control reach UP.

\section{Nutrient retention}

Data on nutrient removal indicate that nitrogen uptake always exceeded phosphorus demand in Fosso Bagnatore. This higher nitrogen uptake was provided in different ways in the two experimental reaches. It was provided mainly by $\mathrm{NO}_{3}-\mathrm{N}$ in UP and mainly by $\mathrm{NH}_{4}$ $\mathrm{N}$ in DW. However $\mathrm{NH}_{4}-\mathrm{N}$ was always removed more efficiently from the water column than $\mathrm{NO}_{3}-\mathrm{N}$ (uptake length ratio $<1$ ). This fact confirmed $\mathrm{NH}_{4}-\mathrm{N}$ to be the preferred nitrogen form by bacteria, fungi and algae (Wetzel 1983). The nutrient uptake rates measured by slug addition experiments refer to gross uptake rather than net retention (Stream Solute Workshop 1990). Nutrient uptake rates are generally linked to local environmental characteristics such as streambed morphology, canopy development, organic matter standing crop, biological community and relative importance of autotrophic and heterotrophic processes (D'Angelo et al. 1991, Martì et al. 1994, Webster et al. 2003, Guecker \& Boëchat 2004). The WWTP effluent increased the uptake rates of ammonium only, but this increase in gross uptake by biota and abiotic sorption was not reflected in the stream nutrient retention efficiency (see below). In fact, the maximum values reported for ammonium uptake rates in this study are much higher than values reported in the literature (Webster et al. 2003, Simon et al. 2005 and references therein). Extremely high values were only detected in DW. In this reach, corresponding $\mathrm{NH}_{4}-\mathrm{N}$ background concentrations were very high and the relatively low values of uptake velocities, detected on the same dates, suggest that uptake rates were low in relation to nutrient supply (Gücker \& Pusch 2006). Accordingly, Haggard et al. (2005) found comparable areal uptake rates for ammonium below a WWTP, where $\mathrm{NH}_{4}-\mathrm{N}$ showed concentrations similar to those detected in this study in DW. All this seems to corroborate that our estimates for ammonium uptake rates can be considered realistic.

Uptake lengths detected in this study were in the range of kilometres, with the exception of the ammonium uptake lengths of April and June, and the nitrate uptake length of March, measured all in the control reach UP. Long uptake lengths indicate a low nutrient removal efficiency of the stream (Stream Solute Workshop 1990) and are generally expected in urban and lowland streams where a nutrient overload of the system occurs along with modifications of compartments involved in nutrient removal function (Haggard et al. 2001, Martì et al. 2004, Merseburger et al. 2005, Meyer et al. 2005, Gücker \& Pusch 2006). We expected a lower nutrient removal efficiency (i.e. longer uptake lengths) downstream of the WWTP effluent, but uptake lengths were not significantly different between the two reaches. On the other hand, we want to stress that values comparable to those found in pristine systems were detected in UP only. The fact that DW values are quite similar to those detected in UP may be explained by a potential adaptation of the biofilm to the heavier load of nutrients in DW (Teissier et al. 2002).

Uptake velocities are often preferred to make intraand inter-site comparisons to avoid variability due to 
discharge differences and to account more for possible differences in biotic demand (Simon \& Townsend 2005). Yet, in our case, uptake velocities were not significantly different between UP and DW for any of the considered nutrients. The temporal and spatial variability of factors controlling nutrient removal in Mediterranean-type streams can be large (Martì et al. 1994, Martì \& Sabater 1996, Merseburger et al. 2005) and may be reflected in a certain difficulty in explaining the observed patterns. In fact, within-stream variation of nutrient uptake is an interesting issue only recently investigated (Simon \& Townsend 2005, Gücker \& Pusch 2006). Among the potential determinants of nutrient uptake in streams, concentrations of metabolic substrates (e.g. nutrients and DOC), FBOM and rates of metabolism have been shown to be particularly important for the control of nutrient uptake in eutrophic/urban streams (Meyer et al. 2005, Gücker \& Pusch 2006). In this study, we have shown how much these variables may naturally change during the year, and in an unpredictable manner, in Fosso Bagnatore (control reach). In addition, the presence of the WWTP effluent contributed to increase the temporal and spatial variability of nutrients, DOC, and fine particulate organic matter (seston and FBOM) in DW. If we consider the uptake velocities calculated in UP together with those from DW, and we calculate the coefficients of variation, we obtain $\mathrm{CV}=48$ for $\mathrm{NH}_{4}-\mathrm{N}, \mathrm{CV}=147$ for $\mathrm{NO}_{3}-\mathrm{N}$ and $\mathrm{CV}=81$ for $\mathrm{PO}_{4}-\mathrm{P}$. In a recent paper, $\mathrm{Si}$ mon \& Townsend (2005) reported the CVs of the uptake velocities measured for the same nutrients in a number of streams. The value we obtained for ammonium is among the highest calculated for combination of dates and sites in a total of 21 streams, while the CVs calculated for $\mathrm{NO}_{3}-\mathrm{N}$ and $\mathrm{PO}_{4}-\mathrm{P}$ are higher than those calculated for 32 and 16 streams respectively (Simon $\&$ Townsend 2005). This comparison allowed us to conclude that in Fosso Bagnatore the uptake of $\mathrm{NH}_{4}$ $\mathrm{N}, \mathrm{NO}_{3}-\mathrm{N}$ and $\mathrm{PO}_{4}-\mathrm{P}$ was highly variable, probably as consequence of the high variability of the compartments involved in this important ecosystem function.

\section{Conclusion}

The influence of climate setting on the biophysical structure of streams in the Mediterranean region (Gasith \& Resh 1999) or in general in arid and semiarid regions (Martì et al. 2000, Meyer \& Meyer 2000) has already been shown. In this climate, the hydrologic regime exerts a stronger control on the ecological functioning of lotic systems. For instance, floods can create a temporal pattern of nutrient cycling, where spiralling lengths are long immediately after floods and then gradually shorten over successional time (Martì et al. 1997, Fisher et al. 1998, Grimm 1988). This study showed that a WWTP effluent can dramatically alter the organic matter dynamics of a Mediterranean-type headwater stream, and thus enhance the strong control of climate on its functioning. We showed that the highly degradable forms of organic matter were affected in particular. As these forms are easily utilized by the biota, WWTP effects on their dynamics were directly reflected in important ecosystem functions such as whole stream metabolism and nutrient removal. Due to the linkage of headwaters to downstream ecosystems and to their significant role in landscape and catchment processes, the alterations of organic matter dynamics that we detected at a local level may have important consequences on a broader scale.

\section{Acknowledgements}

This study was part of the FP5 European Union funded project: Human effects on nutrient cycling in fluvial ecosystems: The development of an Expert System to assess stream water quality management at reach scale (STREAMES, EVK1-CT-2000-00081). We are grateful to M.T. Pusch and B. Gücker for their critical review of the manuscript. This manuscript also benefited from comments by anonymous reviewers. We thank J. Horn for editorial comments on the English text. M. De Cicco, A. Romano, M. Anello and D. von Schiller greatly helped during field work and laboratory analyses. CNR-IRSA made DOC analysis.

\section{References}

Acuña V., Giorgi A., Muñoz I., Uehlinger U. \& Sabater S. 2004. Flow extremes and benthic organic matter shape the metabolism of a headwater Mediterranean stream. Freshwat. Biol., 49, 960971.

Acuña V., Muñoz I., Giorgi A., Omella M., Sabater F. \& Sabater S. 2005. - Drought and postdrought recovery cycles in an intermittent Mediterranean stream: structural and functional aspects. J. N. Am. Benthol. Soc., 24, 919-933.

Ahearn D.S., Sheibley R.W., Dahlgren R.A. \& Keller K.E. 2004. Temporal dynamics of stream water chemistry in the last free-flowing river draining the western Sierra Nevada, California. J. Hydrol., 295, 47-63

Artigas J., Romaní A.M. \& Sabater S. 2004. - Organic matter decomposition by fungi in a Mediterranean forested stream: contribution of streambed substrata. Ann. Limnol. - Int. J. Lim., 40, 269277.

Bañuelos R. Larrañaga S., Elosegi A. \& Pozo J. 2004. - Effects of eucalyptos plantations on CPOM dynamics in headwater streams: a manipulative approach. Arch. Hydrobiol., 159, 211-228.

Belnap J., Welter J.R., Grimm N.B., Barger N. \& Ludwig J.A. 2005. - Linkages between microbial and hydrologic processes in arid and semiarid watersheds. Ecology, 86, 298-307

Benke A.C., Van Arsdall T.C., Gillespie G.M. \& Parish F.K. 1984. Invertebrate productivity in a subtropical blackwater river: the importance of habitat and life history. Ecology, 54, 25-63.

Bernal S., Butturini A. \& Sabater F. 2005. - Seasonal variations of dissolved nitrogen and DOC:DON ratios in an intermittent Mediterranean stream. Biogeochemistry, 75, 351-372.

Brookshire E.N.J. \& Dwire K.A. 2003. - Controls on patterns of co- 
arse organic particle retention in headwater streams. J. N. Am. Benthol. Soc., 22,17-34.

Butturini A. \& Sabater F. 2000. - Seasonal variability of dissolved organic carbon in a Mediterranean stream. Biogeochemistry, 51, 303-321.

Butturini A., Gallart F., Latron J., Vazquez E. \& Sabater F. 2006. Cross-site comparison of variability of DOC and nitrate c-q hysteresis during the autumn-winter period in three Mediterranean headwater streams: a synthetic approach. Biogeochemistry, 77, 327-349.

Cobelas M.A., Rojo C. \& Angeler D.G. 2005. - Mediterranean limnology: current status, gaps and the future. J. Limnol., 64, 13-29.

Costanza R., dArge R., de Groots R., Farber S., Grasso M., Hannon B., Limburg K., Naeem S. O’Neill R.V., Paruelo J., Raskin R.G., Sutton P. \& van den Belt M. 1997. - The value of the world's ecosystem services and natural capital. Nature, 387, 253-260.

Crenshaw C.L., Valett H.M. \& Webster J.R. 2002. - Effects of augmentation of coarse particulate organic matter on metabolism and nutrient retention in hyporheic sediments. Freshwat. Biol., 47, 1820-1831.

D’Angelo D.J. \& Webster J.R. 1991. - Phosphorus retention in streams draining pine and hardwood catchments in the southern Appalachian Mountains. Freshwat. Biol., 26, 335-345.

Dodds W.K., Evans-White M.A., Gerlanc N.M., Gray L., Gudder D.A., Kemp M.J., Lopez A.L., Stagliano D., Strauss E.A., Tank J.L., Whiles M.R. \& Wollheim W.M. 2000. - Quantification of the Nitrogen Cycle in a Praire Stream. Ecosystems, 3, 574-589.

Elosegui A., Arana X., Basaguren A. \& Pozo J. 1995. - Self-purification processes along a medium-sized stream. Environme. Manage., 19, 931-939.

Fischer H., Wanner S.C. \& Pusch M. 2002. - Bacterial abundance and production in river sediments as related to the biochemical composition of particulate organic matter (POM). Biogeochemistry, 61, 37-55.

Fisher S.G., Grimm N.B., Martì E., Holmes R.M. \& Jones J.B. 1998. - Material spiraling in stream corridors: a telescoping ecosystem model. Ecosystems, 1, 19-34.

Gasith A. \& Resh V.H. 1999. - Streams in Mediterranean climate regions: abiotic influences and biotic responses to predictable seasonal events. Ann. Rev. Ecol. Syst., 30, 51-81.

Golladay, S.W. 1997. - Suspended particulate organic matter concentration and export in streams. pages 122-131, in J.R. Webster and J.L. Meyer (editors). Stream organic matter budgets. J. $N$. Am. Benthol. Soc., 16, 3-161.

Golladay S.W., Webster J.R. \& Benfield E.F. 1989. - Changes in benthic organic matter following watershed disturbance. Holarct. Ecol., 12, 96-105.

Gordon N.D., McMahon T.A. \& Finlayson B.L. 1994. - Stream hydrology. John Wiley \& Sons, West Sussex, England, 526 p.

Grimm N.B. 1988. - Role of macroinvertebrates in nitrogen dynamics of a desert stream. Ecology, 69, 1884-1893.

Gücker B. \& Boëchat. I.G. 2004. - Stream morphology controls ammonium retention in tropical headwaters. Ecology, 85, 2818-2827

Gücker B \& Pusch M.T. 2006. - Regulation of nutrient uptake in eutrophic lowland streams. Limnol. Oceanogr., 51, 1443-1453.

Haggard B.E., Storm D.E. \& Stanley E.H. 2001. - Effect of a point source input on stream nutrient retention. J. Am. Water Resour. Assoc., 37, 1291-1299.

Haggard B.E., Stanley E.H. \& Storm D.E. 2005. - Nutrient retention in a point-source-enriched stream. J. N. Am. Benthol. Soc., 24, 29 47.

Harbott E.L. \& Grace M.R. 2005. - Extracellular enzyme response to bioavailability of dissolved organic $\mathrm{C}$ in streams of varying catchment urbanization. J. N. Am. Benthol. Soc., 24, 588-601.
Hauer F.R. \& Lamberti G.A. 1996. - Methods in stream ecology. Academic Press, San Diego, 674 pp.

House W.A. \& Denison F.H. 1997. - Nutrient dynamics in a lowland stream impacted by sewage effluent: Great Ouse, England. Sci. Total Environ., 205, 25-49.

Jones J.B. 1997. - Benthic organic matter storage in streams: influence of detrital import and export, retention mechanisms and climate. J. N. Am. Benthol. Soc., 16, 109-119.

Johnson C.E, Driscoll C.T., Siccama T.G. \& Likens G.E. 2000. - Element fluxes and landscape position in a northern hardwood forest watershed ecosystem. Ecosystems, 3, 159-184.

Karlsson O.M., Richardson J.S. \& Kiffney P.M. 2005. - Modelling organic matter dynamics in headwater streams of south-western British Columbia, Canada. Ecol. Model., 183, 463-476.

Kruschea A.V., Martinelli L.A., Victoria R.L., Bernardesa M., de Camargoa P.B., Ballestera M.V. \& Trumbore S.E. 2002. - Composition of particulate and dissolved organic matter in a disturbed watershed of southeast Brazil (Piracicaba River basin). Wat. Res., $36,2743-2752$.

Lepori F., D. Palm D. \& Malmqvist B. 2005. - Effects of stream restoration on ecosystem functioning: detritus retentiveness and decomposition. J. App. Ecol., 42, 228-238.

Marshall E.J.R. 2004. - Decline in the quality of suspended fine particulate matter as a food resource for chironomids downstream of an urban area. Freshwat. Biol., 49, 515-525.

Martì E., Armengold J. \& Sabater F. 1994. - Day and night nutrient uptake differences in a calcareous stream. Verh. Internat. Verein. Limnol., 25, 1756-1760.

Martì E., Grimm N.B. \& Fisher S.G. 1997. - Pre- and post-flood retention efficiency of nitrogen in Sonoran Desert stream. J. N. Am. Benthol. Soc., 16, 805-819.

Martì E., Fischer S.G., Schade J.D., Welter J.R. \& Grimm N.B. 2000. - Hydrological and chemical linkages between the active channel and the riparian zone in an arid land stream. Verh. Internat. Verein. Limnol., 27, 442-447.

Martì E., Aumatell J., Godé L., Poch M. \& Sabater F. 2004. - Nutrient retention in streams receiving inputs from wastewater tratment plants. J. Environ. Qual., 33, 285-293.

Martì E. \& Sabater F. 1996. - High variability in temporal and spatial nutrient retention in Mediterranean streams. Ecology, 77, 854869

Marzolf E.R., Mulholland P.J. \& Steinman A.D. 1994. - Improvements to the diurnal upstream-downstream dissolved oxygen change technique for determining whole-stream metabolism in small streams. Can. J. Fish. Aquat. Sci., 51, 1591-1599.

Merseburger G.C., Marti E. \& Sabater, F. 2005. - Net changes in nutrient concentrations below a point source input in two streams draining catchments with contrasting land uses. Sci. Total Environ., 347, 217-229.

Meixner T. \& Fenn M. 2004. - Biogeochemical budgets in a Mediterranean catchment with high rates of atmospheric $\mathrm{N}$ deposition - importance of scale and temporal asynchrony. Biogeochemistry, 70, 331-356.

Meyer A. \& Meyer E.I. 2000. - Discharge regime and the effect of drying on macroinvertebrate communities in a temporary karst stream in East Westphalia (Germany). Aquat. Sci., 62, 216-231.

Meyer J.L., Paul M.J. \& Taulbee W.K. 2005. - Stream ecosystem function in urbanizing landscapes. J. N. Am. Benthol. Soc., 24, 602-612.

Mulholland P.J., Fellows C.S., Tank J.L., Grimm N.B., Webster J.R., Hamilton S.K., MartÏ E., Ashkenas L., Bowden W.B., Dodds W.K., McDowell W.H. Paul M.J. \& Peterson B.J. 2001. - Interbiome comparison of factors controlling stream metabolism. Freshwater Biol., 46, 1503-1517. 
Munn, N.L. \& Meyer J.L. 1990. - Habitat-specific solute retention in two small streams: an intersite comparison. Ecology, 71, 20692082

Ortiz J.D., Martì E. \& Puig M.A. 2005. - Recovery of the macroinvertebrate community below a wastewater treatment plant input in a Mediterranean stream. Hydrobiologia, 545, 289-302.

Owens, M. 1974. - Measurements on non-isolated natural communities in running waters. In A manual on methods for measuring primary production in aquatic environments. Edited by R.A. Vollenweider. Blackwell Scientific Publications, Oxford. pp. 111-119.

Perakis S.S. \& Hedin L.O. 2002. - Nitrogen loss from unpolluted South American forests mainly via dissolved organic compounds. Nature, 415, 416-419.

Peterson B.J., Wollheim W.M., Mulholland P.J., Webster J.R., Meyer J.L., Tank J.L., Martì E., Bowden W.B., Valett H.M., Hershey A.E., McDowell W.H., Dodds W.K., Hamilton S.K., Gregory S. \& Morrall D.D. 2001. - Control of Nitrogen Export from Watersheds by Headwater Streams. Science, 292, 86-90.

Prior H. \& Johnes P.J. 2002. - Regulation of surface water quality in a Cretaceous Chalk catchment, UK: an assessment of the relative importance of instream and wetland processes. Sci. Total Environ., 282-283, 159-174.

Rauter A., Weigelhofer G., Waringer J. \& Battin T.J. 2005. - Transport and metabolic fate of sewage particles in a recipient stream. J. Environ. Qual., 34,1591-1599.

Resh V.H., Jackson J.K. \& McElravy E.P. 1990. - Disturbance, annual variability, and lotic benthos: examples from a California stream influenced by a mediterranean climate. Mem. Ist. Ital. Idrobiol., 47, 309-329.

Robinson C.T. \& Jolidon C. 2005. - Leaf breakdown and the ecosystem functioning of alpine streams. J. N. Am. Benthol. Soc., 2005 , 24, 495-507.

Ruggiero A., Solimini A.G., Anello M., Romano A., De Cicco M. \& Carchini G. 2006. - Nitrogen and phosphorus retention in a human altered stream. Chemist. Ecol., in press.

Simon K.S., Townsend C.R., Biggs B.J.F. \& Bowden W.B. 2005. Temporal variation of $\mathrm{N}$ and $\mathrm{P}$ uptake in 2 New Zeland streams. $J$. N. Am. Benthol. Soc., 24, 1-18.

Speaker R., Moore K. \& Gregory S. 1984. - Analysis of the process of retention of organic matter in stream ecosystem. Verh. Internat. Verein. Limnol. 22, 1835-1841.
Stream Solute Workshop 1990. - Solute dynamics in streams. J. N. Am. Benthol. Soc., 9, 95-119.

Teissier S., Garabetian F. , Torre M., Dalger D. \& Labroue L. 2002 - Impact of an urban centre on the nitrogen cycle processes of epilithic biofilms during a summer low-water period. Riv. Res. Appl., 18,2130

Tockner K., Ward J.V., Arscott D. B., Edwards P.J., Kollmann J., Gurnell A.M., Petts G.E. \& Maiolini B. 2003 - The Tagliamento River: a model ecosystem of European importance. Aquat. Sci. 65, 239-253.

Ulseth A.J. \& Hershey A.E. 2005. - Natural abundances of stable isotopes trace anthropogenic $\mathrm{N}$ and $\mathrm{C}$ in an urban stream. $J . N$. Am. Benthol. Soc., 24, 270-289.

Vannote R.L., Minshall G.W., Cummins K.W., Sedell J.R \& Cushing C.E. 1980. - The river continuum concept. Can. J. Fish Aquat. Sci., 37, 130-137.

Vidal-Abarca, M.R., Suarez M.L., Guerrero C., Velasco J., Moreno J.L., Millán A. \& Perán A. 2001 - Dynamics of dissolved and particulate organic carbon in a saline and semiarid stream of southeast Spain (Chicamo stream). Hydrobiologia, 455, 71-78

Webster J.R., Mulholland P.J., Tank J.L., Valett H.M., Dodds V.K. Peterson B.J., Bowden W.B., Dahm C.N., Findlay S., Gregory S.V., Grimm N.B., Hamilton S.K., Johnson S.L., MartÏ E., McDowell W.H., Meyer J.L., Morrall D.D., Thomas S.A. \& Wollheim W.M. 2003. - Factors affecting ammonium uptake in streams - an inter-biome perspective. Freshwat. Biol., 48, 13291352.

Webster J.R., Tank J.L., Wallace J.B., Meyer J.L., Eggert S.L., Ehrman T.P., Ward B.R., Bennett B.L., Wagner P.F. \& McTammany M.E. 2000. - Effects of litter exclusion and wood removal on phosphorus and nitrogen retention in a forest stream. Verh. Internat. Verein. Limnol., 27, 1337-1340.

Webster J.R., Golladay S.W. Benfield E.F., D’Angelo D.J. \& Peters G.T. 1990. - Effects of forest disturbance on particulate organic matter budgets of small streams. J. N. Am. Benthol. Soc., 9, 120140.

Wetzel R.G. 1983. - Limnology. Second Edition. Saunders College Publishing, $860 \mathrm{pp}$

Wetzel R.G. \& Likens G.E. 1991. - Limnological Analyses. Springer-Verlag, New York, 391 pp. 